\title{
Nauka o architekturze informacji: koncepcja dyscypliny naukowej
}

\author{
Stanisław Skórka \\ ORCID 0000-0003-4876-8660 \\ Instytut Nauk o Informacji, \\ Uniwersytet Pedagogiczny w Krakowie
}

\begin{abstract}
Abstrakt
Cel/Teza: Celem artykułu jest próba odpowiedzi na pytanie, czy architektura informacji jest dyscypliną naukową. Jeżeli tak, to co odróżnia ją od nauki o informacji (informatologii)?

Koncepcja/Metody badań: Wykorzystano analizę i krytykę piśmiennictwa oraz metodę porównawczą. Analizę architektury informacji pod względem posiadania cech dyscypliny naukowej przeprowadzono na podstawie trzech kryteriów: pola badawczego, teorii, metodologii.

Wyniki i wnioski: Nauka o architekturze informacji (NAI) wykorzystuje paradygmaty i teorie innych dyscyplin, np. architektury, informatologii, nauki o komunikacji społecznej i mediach. Zadaniem NAI powinno być badanie zjawisk wpływających na odnajdywanie informacji przez człowieka, ale także na efektywność w zarządzaniu informacją, w tym również poszukiwanie nowych narzędzi, metod, inspiracji do wspierania tych działań. Badacze architektury informacji mogą szukać odpowiedzi na pytanie: czy forma informacji wyraża jej przeznaczenie? Trudno wskazać oryginalną metodę badawczą charakterystyczną dla tej dyscypliny.

Oryginalność/Wartość poznawcza: Różnica między NAI a informatologią dotyczy obszarów działań. Nauka o informacji zajmuje się naturą informacji, bada jej cechy i właściwości, koncentruje się na procesie informacyjnym w sensie całościowym. Zadaniem NAI będzie badanie zjawisk wpływających na odnajdywanie informacji przez człowieka, na efektywność w zarządzaniu informacją oraz poszukiwanie odpowiedzi na pytanie o to, czy forma informacji wyraża jej przeznaczenie.
\end{abstract}

\section{Słowa kluczowe}

Architektura informacji. Dyscyplina naukowa. Informatologia. Interdyscyplinarność. Metodologia. Nauka o informacji. Pole badawcze. Teoria.

Otrzymany: 7 listopada 2020. Z Zrecenzowany: 30 listopada 2020. Poprawiony: 14 stycznia 2021. Zaakceptowany: 8 marca 2021.

\section{Wprowadzenie}

Idea architektury informacji (AI) liczy już 45 lat, po raz pierwszy została przedstawiona w artykule Beyond Graphics: The Architecture of Information (Wurman \& Katz, 1975). Od tego czasu rozwinęła się technologia, zwiększyła różnorodność formatów i nośników, a przede wszystkim wzrosła ilość informacji, z którą człowiek wchodzi w interakcję w różnych miejscach i w różnych chwilach swojego życia. AI stała się m.in. specjalnością zawodową, skupioną na projektowaniu funkcjonalnych i przyjaznych dla użytkownika cyfrowych środowisk informacyjnych. Od pewnego czasu można zauważyć także trend kształtowania się AI jako związanego z tą specjalnością obszaru badań naukowych, aspirującego do 
statusu subdyscypliny, a nawet dyscypliny naukowej. Niniejszy artykuł poświęcony jest koncepcji architektury informacji jako nauki interdyscyplinarnej. Autor używa określenia „nauka o architekturze informacji” (NAI) jako nazwy tej dyscypliny w celu odróżnienia jej od terminu architektura informacji, którego znaczenie, za Louisem Rosenfeldem, Peterem Morville'em i Jorge Arango (2017, 33) odnosi się najczęściej do struktury i organizacji projektowanego środowiska informacyjnego lub do specjalności praktycznej związanej z takim projektowaniem. Celem artykułu jest próba odpowiedzi na trzy pytania:

(1) Czy istnieje nauka o architekturze informacji?

(2) Czy AI może być samodzielną dyscypliną?

(3) Czy i co odróżnia ją od nauki o informacji?

Autor posłużył się następującymi metodami badań: (a) analizą i krytyką piśmiennictwa (na etapie poszukiwań literatury przedmiotu dotyczącej koncepcji NAI, jej metodologii, teorii oraz selekcji przykładów ich zastosowania); (b) metodą porównawczą, która pozwoliła m.in. na zestawienie poglądów i opinii dotyczących zadań i funkcji NAI jako dyscypliny naukowej.

Analiza i krytyka piśmiennictwa pozwoliła autorowi rozważyć kwestię posiadania przez naukę o architekturze informacji cech dyscypliny naukowej w odniesieniu do trzech kryteriów wskazanych przez Jerzego Ratajewskiego $(2002,10)$ jako główne kryteria identyfikacji dyscyplin naukowych: (a) pola badawczego i przedmiotu badań; (b) teorii, tj. zespołu twierdzeń przypisanych tej nauce; (c) metodologii, dzięki której dyscyplina bada określone obiekty, realizując swoje cele. Jerzy Ratajewski do atrybutów nauki zaliczył ponadto: język, którym posługuje się dana nauka; miejsce danej dyscypliny w ogólnym systemie nauk; zapotrzebowanie społeczne na badania naukowe w określonym kierunku nauki (Ratajewski, 2002, 10).

Na podstawie trzech pierwszych kryteriów autor poddał analizie dorobek badawczy AI dążąc do sprawdzenia, czy spełnia ona te wymagania.

Na podstawie tzw. kryteriów instytucjonalnych za dyscypliny naukowe uznawane są również takie obszary badań naukowych, którym odpowiadają kierunki studiów wykładane na uczelniach i problematyka badań prowadzonych w ramach wyodrębnionych jednostek organizacyjnych uczelni, tj. wydziałów lub instytutów (Kozłowski, 1996, 4; Pilch, 1998, 3). Autor poświęcił więc uwagę także kształceniu akademickiemu w zakresie AI. Ponadto w artykule zostało zawarte omówienie stanu badań związanych z AI, analiza przedmiotu tych badań, teorii oraz metod badawczych, które są w nich stosowane, a także zarys koncepcji NAI.

\section{Stan badań}

Jak wspomniano, pojęcie architektury informacji łączy się przeważnie z działalnością praktyczną (rzemiosłem) (Morrogh, 2002), projektowaniem środowisk lub przestrzeni informacyjnych (Dillon, 2002; Morrogh, 2002, 6), projektowaniem serwisów internetowych (Dijck, 2003, 12), organizowaniem informacji (Spencer, 2010, 4). W najczęściej cytowanych definicjach architektury informacji stwierdza się, że AI jest:

- wschodzącą dyscypliną i społecznością praktyków skupioną na dostarczaniu zasad projektowania i architektury do cyfrowego krajobrazu;

- $\quad$ sztuką oraz nauką kształtowania produktów informacyjnych i doświadczeń w celu wspierania użyteczności, możliwości wyszukania i zrozumienia informacji (Rosenfeld et al., 2017, 33). 
Przytoczone definicje nie wystarczają jednak do uzasadnienia twierdzenia, że architektura informacji spełnia kryteria dyscypliny naukowej. Mocniej podkreślono w nich praktyczny niż badawczy charakter architektury informacji.

Szerzej na temat AI jako dyscypliny naukowej lub obszaru badań naukowych wypowiadali się następujący autorzy: Marcia Bates (2007), Martyn Dade-Robertson (2011), Nathaniel Davis (2010, 2018), D. Grant Campbell (2006, 2007), Brian A. de Hubert-Miller (2006), Flávia Lacerda i Mamende Lina-Marques (2014), Andrea Resmini i Luca Rosati (2011). Z polskich autorów temat ten podejmowali m.in.: Marcin Roszkowski (2019), Stanisław Skórka (2016), Barbara Sosińska-Kalata (2013, 2017), Piotr Tafiłowski (2016) i Dorota Utracka (2017). Niektórzy z wymienionych autorów poszukiwali odpowiedzi na pytania, czy AI może być samodzielną dyscypliną (Campbell, 2006; Davis 2010, 25; Utracka, 2017; Roszkowski, 2019), czy i jakie fundamenty teoretyczne posiada AI, aby uznać ją za samodzielną naukę (Huber-Miller, 2006, 11), z którymi dziedzinami dzieli swoje pole badawcze (Davis, 2018). Andrew Dillon (2003) przyznał, iż to, czym zajmują się architekci informacji nie jest całkowicie nowe, np. potrzebę badań z udziałem użytkowników podczas projektowania produktu postulował już w 1930 r. Henry Dreyfuss (Dillon, 2003, 27). Jak dotąd nie ukazała się publikacja w języku polskim poświęcona naukowemu kierunkowi rozwoju AI oraz jej miejscu wśród innych dyscyplin nauki. Jesse James Garret (2002) uważa, iż dla prawidłowego rozwijania się dyscypliny AI niezbędne jest odpowiednie jej zdefiniowanie, zawężające jej granice. Pozwoliłoby to opisać konkretne problemy badawcze AI w sposób precyzyjny.

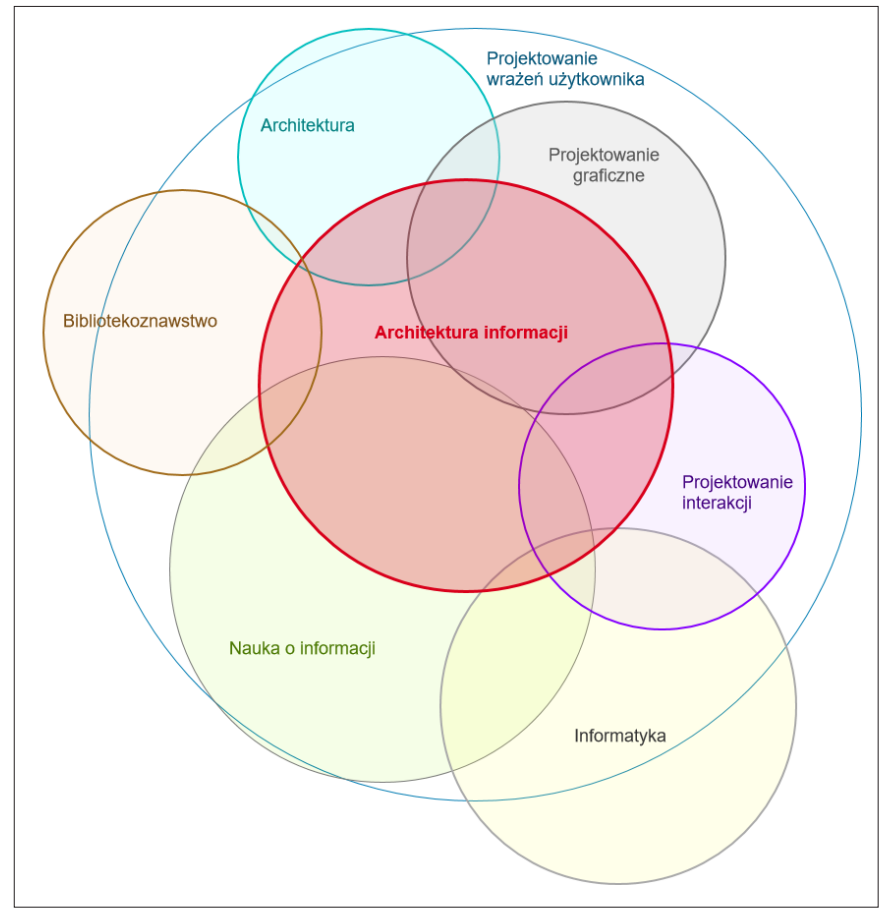

Rys. 1. Dyscypliny powiązane z architekturą informacji. Oprac. własne na podstawie: Saffer, 2010, 21 
Birger Hjørland (2012, xxii) a także Barbara Sosińska-Kalata (2017) zaliczyli AI do subdyscyplin nauk o informacji. Natomiast Marcia Bates (2007) w swojej koncepcji umieściła AI wśród subdyscyplin informacyjnych (ang. information sub-disciplines) należących do zakresu tzw. nauk informacyjnych (ang. sciences of information). Różne subdyscypliny informacyjne, zdaniem $\mathrm{M}$. Bates, powiązane są z różnymi dziedzinami wiedzy, zajmując się generowaną przez nie informacją i korzystając z ich warsztatu badawczego. W grupie subdyscyplin informacyjnych architektura informacji znajduje się w obszarze związanym z naukami społecznymi oraz przyrodniczymi i matematycznymi, które charakteryzują się m.in. podejściem nomotetycznym, tj. poszukiwaniem ogólnych praw i zasad ${ }^{1}$. AI zaliczana jest także do grona dyscyplin mieszczących się w rozległym obszarze zwanym projektowaniem wrażeń użytkowników (ang. user experience design) obok architektury, projektowania wizualnego, interakcji człowiek-komputer, inżynierii użyteczności, informatyki projektowania interakcji i wielu innych (Rys. 1) (Davis, 2011; Saffer, 2009, 21).

\section{Pole badawcze NAI}

Posiadanie własnego przedmiotu badań nie jest elementem decydującym o wyodrębnieniu się dyscypliny naukowej, według Karola Poppera jest nim rodzaj problemów naukowych (Sosińska-Kalata, 2013, 24). Jerzy Apanowicz $(2003,51,53)$ wyróżnił sześć rodzajów problemów badawczych ze względu na zakres, przedmiot, stan badań itp.:

- problemy teoretyczne, prowadzące do gromadzenia wiedzy teoretycznej, formułowania praw i koncepcji, np. zagadnienia terminologiczne, miejsce AI wśród innych dyscyplin projektowych (stosowane w badaniach podstawowych);

- problemy praktyczne, dotyczące realnych potrzeb związanych m.in. z projektowaniem i ewaluacją środowisk informacyjnych, np. zastosowanie metody sortowania kart do ewaluacji architektury informacji, wrażenia użytkowników wyszukujących produktów w określonym serwisie, aplikacji, interfejsie itp. (wykorzystywane w badaniach stosowanych);

- problemy podstawowe, mogą dotyczyć teorii, sformułowania koncepcji, być związane ze zmianą paradygmatu, np. strukturalistyczna koncepcja badań systemów informacyjnych;

- problemy cząstkowe, skupione na wycinku tematu, fragmencie rzeczywistości, kontekście, np. rodzaje etykiet w systemie nawigacji lokalnej określonej aplikacji;

- problemy ogólne, obejmujące szeroki zakres badań z wykorzystaniem kilku metod badawczych, np. kamienie milowe rozwoju architektury informacji od czasów prehistorycznych do XXI w.;

- problemy szczegółowe, wykorzystujące większą liczbę metod i technik badawczych, dotyczą węższego obszaru, ale badanego możliwie wszechstronnie, np. rodzaje zachowań informacyjnych użytkowników elektronicznego katalogu biblioteki (badania kompleksowe).

W zestawieniu tematycznym z zakresu architektury informacji, opracowanym przez Petera Morville’a (2004), publikacje pogrupowano według czterech kategorii: zachowania informacyjno-wyszukiwawcze, struktura i organizacja (informacji), nawigacja, wyszukiwanie.

1 Alternatywą jest podejście idiograficzne, skupiające się na indywidualnych i unikalnych cechach danego zjawiska - charakterystyczne dla nauk humanistycznych, por. M. Bates (2007). 
Podział ten można uznać za pewien rodzaj koncepcji pola badawczego, którym zajmują się badacze i praktycy AI. Z kolei analizując kontekst, w którym osadzany jest główny przedmiot badań NAI, tj. funkcjonalne i przyjazne dla użytkownika środowiska informacyjne (w szczególności cyfrowe), można wskazać trzy ogólne obszary:

(1) zagadnienia związane ze środowiskiem informacyjnym, rozumianym jako otoczenie informacyjne człowieka (por. Kisilowska, 2011, 42), w tym z projektowaniem i ewaluacją jego elementów składowych;

(2) zagadnienia dotyczące użytkowników znajdujących się w takim środowisku, ich zachowaniami informacyjnymi (m.in. wyszukiwaniem, nawigacją, wykorzystaniem informacji), potrzebami, interakcjami i wrażeniami;

(3) relacje pomiędzy dwiema powyższymi kategoriami problemów, np. poszukiwanie odpowiedzi na pytania o to, w jakim stopniu struktura, zakres, kontekst warunkują zachowanie informacyjne użytkownika, który element informacji (treść, kod, kształt) wpływa na zrozumienie przez niego przekazanej treści w określonym kontekście i warunkach, a także na łatwość w przemieszczaniu się w przestrzeni informacyjnej itp.

Obszar zainteresowań NAI obejmuje zatem środowiska informacyjne badane z punktu widzenia:

- projektowania, tj. nadawania im kształtu, struktury, organizowania treści, łączenia nawigacją;

- komunikowania - np. zastosowania odpowiedniego kodu i formy do utrwalenia i przekazu treści;

- ewaluacji - oceny np. zastosowanych kategorii zawartości, metadanych, składowych ułatwiających zrozumienie, efektywności systemów nawigacji itp.

Badania AI dotyczyć mogą również elementów tzw. ekosystemów informacyjnych, które wspierają użytkownika podczas interakcji z pewnym produktem informacyjnym (np. dialogu z aplikacją). Ekosystem informacyjny to złożony układ adaptacyjny zajmujący pewną przestrzeń, składający się z infrastruktury informacyjnej oraz społeczności korzystającej z tej infrastruktury (producentów, konsumentów, projektantów), w którym występuje interakcja i przepływ informacji pomiędzy elementami tego układu. Do infrastruktury informacyjnej należą: systemy organizacji treści, nawigacji, wyszukiwania, interfejsy użytkownika, etykiety, wizualizacja informacji, kod zastosowany do komunikacji. Jednym z wyzwań NAI jest mierzenie efektywności tych systemów oraz wzajemnych relacji pomiędzy nimi, w celu zaspokojenia oczekiwań użytkowników oraz ulepszenia wymiany informacji (Davis, 2012).

NAI opierać się może na paradygmacie inspirowanym architekturą, tj. aranżowaniem i porządkowaniem informacyjnego otoczenia człowieka, którego bogactwo i różnorodność form przekazu informacji są przyczyną chaosu i dezinformacji. Dlatego za główne cele architektury informacji uznać można ułatwienie człowiekowi czerpania z tego bogactwa i wykorzystania dla własnych celów treści dostępnych we współczesnych ekosystemach informacyjnych w postaci danych, informacji i komunikatów. Oznacza to, że do nadrzędnych zadań NAI należeć powinno badanie zjawisk wpływających na efektywność odnajdywania informacji przez człowieka, a także na efektywność procesów zarządzania informacją, tj.: planowania, organizowania, finansowania i wykorzystywania informacji (Babik, 2019, 17-18), oraz poszukiwanie nowych narzędzi, metod, inspiracji do wspierania tych działań. Idąc śladem koncepcji rozwijanych w architekturze, badacze architektury informacji mogą szukać odpowiedzi na takie pytania jak: 
- Czy forma informacji wyraża jej przeznaczenie?²

- Na ile zastosowanie i przeznaczenie informacji jest uwarunkowane jej kształtem lub formatem?

- Jaką rolę odgrywa kod zastosowany do przekazania treści?

- Jakie relacje występują pomiędzy elementami architektury informacji, m.in. pomiędzy kodem a treścią, systemem nawigacji a systemem organizacji informacji, wiedzą użytkownika a jego zachowaniem podczas interakcji w przestrzeni informacyjnej?

Tematyka związana z komunikowaniem wydaje się być również naturalnym obszarem badań dla AI. Pojawia się możliwość integrowania z polem badawczym oraz metodologią nauk o komunikacji. Czerpiąc z teorii stosowanych w naukach o komunikacji, w NAI wykorzystana być może koncepcja obszarów badawczych Harolda D. Lasswela (Michalczyk, 2019, 34-36). Należą do nich:

- obszar komunikatorów, czyli osób biorących udział w komunikowaniu (procesie przekazywania informacji), tj. nadawcy komunikatów (autorzy treści), właściciele mediów (np. witryn, aplikacji itp.) oraz pośredniczący w ich nadawaniu (projektanci, architekci informacji, specjaliści od interakcji człowiek-komputer);

- obszar zawartości - odpowiadający na pytanie, co jest komunikowane?, co jest treścią wypowiedzi i jej formą, typy mediów, rodzaj kanału (cyfrowy - tradycyjny, mobilny - desktopowy);

- obszar publiczności i recepcji - poznanie odbiorców i sposobów korzystania przez nich z elementów AI (systemów nawigacji, wyszukiwania, organizacji informacji i etykietowania), stopień indywidualizacji interakcji z treścią;

- obszar skutków - efekt oddziaływania mediów (informacji) w płaszczyźnie mikro zmiana stanu wiedzy u odbiorcy (skutki kognitywne), wywołanie emocji (afektywne), zmiana motywu zachowań (skutki konatywne), w płaszczyźnie makro - wpływ na postawy społeczne (Michalczyk, 2019, 36).

Przedmiotem dociekań badawczych NAI mogą stać się elementy AI opisane w książce L. Rosenfelda, P. Morville'a i J. Arango (2017) - np. systemy organizacji treści, nawigacji, wyszukiwania i etykietowania, występujące w:

- interfejsach dotykowych aplikacji mobilnych, ekranów dotykowych w bankomatach, paczkomatach, biletomatach, urządzeniach peryferyjnych itp.;

- informacjach o specjalnym zastosowaniu, np. w instrukcjach montażu mebli, instalacji programu lub urządzeń AGD, w przepisach kulinarnych, systemach informacyjnych, bazach danych itp.

Wśród zagadnień badawczych NAI nie powinno zabraknąć aspektu humanistycznego, tj.:

- badania stopnia zrozumienia lub percepcji treści zawartej w określonej informacji, np. instrukcjach bezpieczeństwa w samolotach, infografikach, formularzach urzędowych, takich jak formularze PIT i umów itp.;

- testowania użyteczności produktów informacyjnych (aplikacji mobilnych, baz danych itp.);

2 W tym kontekście można zacytować objaśnienie funkcji architektury przedstawione przez Adolfa Loosa, cytowane za Antonio Monestriroli: „Gdy znajdziemy w lesie kopiec długi na sześć stóp i szeroki na trzy, w kształcie piramidy, poważniejemy i coś mówi nam w głębi: tutaj jest pochowany człowiek. To jest architektura" (Monestriroli, 2004, 10). 
- analizy relacji pomiędzy człowiekiem a środowiskiem, czy raczej ekosystemem informacyjnym, które wyrazić można pytaniem problemowym zadanym przez R.S. Wurmana $(1996,16)$ : co sprawia, że informacja informuje?

Lista tematów badawczych dla NAI obejmować powinna również analizę zastosowania w praktyce określonych umiejętności architektów informacji, do których Nathaniel Davis zaliczył: projektowanie nawigacji, organizację informacji, budowanie relacji między informacjami, zarządzanie AI, strategię AI oraz badania architektury informacji (Davis, 2011).

Powyższy przegląd pokazuje różnorodność zagadnień należących do obszaru badawczego NAI. Jednocześnie podkreślić należy, że w przedstawionym omówieniu nie ujęto wszystkich potencjalnych problemów, które mogą interesować badacza architektury informacji. Wiele z nich ma charakter interdyscyplinarny, łącząc problematykę badawczą NAI z obszarami zainteresowań m.in. socjologii, psychologii, projektowania graficznego, językoznawstwa oraz nauki o komunikacji społecznej i mediach.

\section{Teoria w NAI}

W szerokim ujęciu, które zostało przyjęte w niniejszym artykule, badania teoretyczne w nauce obejmują m.in. systematyzowanie pojęć, koncepcji, paradygmatów i twierdzeń leżących u podstaw danej dyscypliny. Teoria naukowa w sensie wąskim definiowana jest jako system twierdzeń logicznie i rzeczowo uporządkowanych, powiązanych określonymi stosunkami logicznymi występującymi w danej nauce, oraz spełniających przyjęte w niej kryteria naukowości i poprawności metodologicznej (Teoria naukowa, b.d.). Początkiem sformułowania teorii może być hipoteza, czyli zdanie twórcze o domniemanym stanie rzeczy, która wyjaśnia jakieś fakty lub definiuje określony termin teoretyczny (Kamiński, 1992, 214). Do funkcji teorii naukowej należą:

- eksplanacja, interpretacja lub porządkowanie (łączenie w spójny obraz) faktów;

- wyjaśnianie i interpretacja systemowa praw;

- generowanie nowych hipotez;

- ustalanie sensu terminów teoretycznych oraz nadawanie statusu istnienia desygnatom;

- przewidywanie nowych faktów;

- optymalizacja procedur badawczych (zmiana tez na reguły) (Kamiński, 1992, 225).

Z jakich teorii korzystać może NAI? Praktyczna AI posługuje się zasadami (wzorcami, regułami) do projektowania użytecznych środowisk informacyjnych, interfejsów, interakcji użytkownika. Wielu autorów natomiast dostrzegło słabość podstaw teoretycznych w nauce o architekturze informacji (np. Bawden \& Robinson, 2012, 143; Fast, 2006; Haverty, 2002, 839; Hubert-Miller, 2006, 10). Nie jest to zjawisko rzadkie, w początkach swojego rozwoju bibliotekoznawstwo oraz nauka o informacji również zmagały się z problemem niedostatecznych podstaw teoretycznych (por. Ingwersen, 1995, 141; Ratajewski, 2002, 55).

Teorię w NAI tworzyć mogą więc systemy pojęć i definicji, aksjomatów i twierdzeń opisujących relacje społeczne, przestrzenne i kulturowe pomiędzy elementami środowisk informacyjnych i ich użytkownikami. Podstawy teoretyczne architektura informacji czerpie z teorii swoich dyscyplin pokrewnych, m.in. z nauki o informacji (informatologii), architektury, nauki o komunikacji społecznej i mediach, informatyki. Istotną kwestią pozostaje 
jednak to, czy NAI wypracowała własne prawa, zasady, paradygmaty mogące świadczyć o samodzielności dyscypliny?

Pierwsze koncepcje teoretyczne w AI powstały na początku kształtowania się praktyki zawodowej w tym zakresie, tj. w latach 90. XX w., kiedy w piśmiennictwie toczyła się również dyskusja nad miejscem AI wśród innych zawodów oraz innych dziedzin projektowych. Zwieńczeniem dyskusji AI był pierwszy zjazd architektów informacji, zorganizowany pod auspicjami American Society for Information Science w 2000 r. - ASIS Summit w Bostonie (Peek, 2000, 14, 16, 18). Przytoczone w niniejszym artykule definicje oraz wymienione w poprzednim punkcie kierunki zainteresowań wskazują, iż główne wątki teorii NAI mogą dotyczyć:

(1) koncepcji i zasad konstruowania zrozumiałych dla użytkownika struktur informacji;

(2) kryteriów wspierających i ułatwiających zrozumienie informacji przez jej odbiorcę;

(3) zastosowania odpowiedniego systemu kodu i nadawania kształtu informacji;

(4) zasad projektowania i badania funkcjonalności systemów nawigacji oraz wyszukiwania;

(5) zachowań i strategii wyszukiwawczych użytkowników produktów informacyjnych.

Wśród teorii NAI można wyróżnić kierunek interdyscyplinarny, tzn. koncepcje, paradygmaty, twierdzenia zaczerpnięte z innych dziedzin oraz kierunek organiczny, do którego zaliczyć można teorie skonstruowane w wyniku m.in. doświadczeń i weryfikacji hipotez badawczych uzyskanych w ramach badań nad AI.

Do grupy interdyscyplinarnej zaliczyć można wykorzystywane w AI teorie wypracowane w architekturze, związane z przestrzenią urbanistyczną, takie jak teoria budowy przestrzeni architektonicznej Kevina Lyncha (2011), zakładająca, że struktura miasta składa się z pięciu elementów: dróg, krawędzi, rejonów, węzłów i punktów orientacyjnych (Lynch, 2011, 53-104). Do grupy tej należą też teoria orientacji przestrzennej i tzw. wayfindingu (odkrywania drogi) Romedi Passiniego (1992), teoria znaku, która wykorzystywana jest zarówno w architekturze (Niezabitowska 2014,55), jak i w nauce o komunikacji społecznej i mediach (McQuail, 2012, 343), teoria koloru (Ludwin, 2017, 24-89). Projektowanie i badanie elementów AI, np. systemów nawigacji, czy interfejsów użytkownika, opiera się na teoriach związanych z procesami przetwarzania informacji u człowieka, m.in. na teorii percepcji (Kalbach, 2007, 244-246), torii rozpoznawania obrazów, rozwiązywania problemów, uczenia się, podejmowania decyzji, które powstały i wykorzystywane są w psychologii (Lindsay \& Norman, 1984), ale są też źródłem interpretacji pozwalającym wyjaśniać preferencje, zachowania i wrażenia użytkowników podczas interakcji w rozmaitych ekosystemach informacyjnych.

W grupie teorii organicznych dominuje założenie, iż każda informacja posiada własną architekturę informacji. Do grupy tej należą: koncepcja powszechnej architektury informacji (ang. pervasive information architecture) A. Resminiego i Luca Rosatiego (2011), w której zaakcentowano międzykanałową interakcję użytkownika (interakcję między różnymi środowiskami informacji); perspektywa hermeneutyczna AI zaproponowana przez Marcina Roszkowskiego (2019) - w koncepcji tej istotną rolę w interpretacji struktury informacji odgrywa kontekst, znaczenie i wrażenia użytkownika; wybrane reguły i twierdzenia z tzw. 25 tez architektury informacji ${ }^{3}$.

3 Wśród 25 tez AI wymienione są m.in. następujące: (1) Tak jak rewolucja kopernikańska zmieniła paradygmat nie tylko w astronomii, tak Internet zmienił nasz paradygmat nie tylko w zakresie technologii. 
Do teorii organicznych o mniejszym zasięgu (Michalczyk, 2019, 76) zaliczyć można postulaty sformułowane w wyniku praktycznych doświadczeń w projektowaniu AI ujętych w postać, tzw. zasad architektury informacji Dana Browna (2010), które wskazują na osiem aspektów istotnych dla zapewnienia funkcjonalności środowiska informacyjnego i wyszukiwalności informacji ${ }^{4}$. Należą do nich reguły:

(1) obiektów - traktowanie zawartości, jako żywego, dynamicznego przedmiotu, z własnym cyklem życia, zachowaniami i cechami;

(2) wyborów - tworzenie logicznych dla użytkowników opcji związanych z kontekstem realizowanego zadania, ułatwiających dokonywanie selekcji spośród wielu wariantów;

(3) ujawniania - pokazywanie tylko tych informacji, które pomogą ludziom zrozumieć, jaką informację otrzymają, gdy będą szukać głębiej;

(4) wspierania się przykładami - np. opisywanie kategorii, poprzez pokazanie przykładu jej zawartości;

(5) drzwi frontowych - co najmniej połowa użytkowników witryny wejdzie do niej inną drogą, niż przez stronę główną, dlatego każda z podstron powinna zawierać dane lokalizacyjne tytuł większej całości itp.;

(6) klasyfikacji wielokrotnej - oferowanie użytkownikom kilku różnych schematów organizacji informacji ułatwiających przeglądanie zawartości witryny wg innych kryteriów;

(7) nawigacji skupionej (fokusowej) - ułatwianie znajdowania informacji za pomoca różnych rodzajów i mechanizmów nawigacji dopasowanych do kontekstu;

(8) wzrostu - przechowywanie treści, które nie są już istotne lub aktualne, ale mogą być ponownie wykorzystane (Brown, 2010).

Również idee związane z obszarem user experience mieszczą się w grupie koncepcji organicznych NAI, a wśród nich m.in.: teorie zdobywania informacji (ang. information foraging theory) oraz tropu informacji (ang. information scent) Petera Pirollego (2007, 68) - skupiona na wspieraniu użytkowników w dotarciu do poszukiwanej informacji dzięki pozostawionym przez projektującego wskazówkom.

W teorii NAI swoje miejsce znajdzie także pochodzące z semiologii kultury (Eco 2003, 200) twierdzenie, iż architektura może coś komunikowaćs . Jeżeli ludzie przeżywają architekturę jako fakt komunikacyjny (Eco, 2003, 201), można przyjąć też, iż analogicznie jak architektura również AI pełni funkcję komunikatywną, tj. ułatwia zrozumienie poprzez komunikowanie swojej funkcji - realizując zasadę, że „forma idzie za funkcją” (Eco, 2003,

Obecnie oczekujemy, że wszystkie środowiska informacyjne będą równie dostępne, natychmiastowe i totalne; (2) Jednym z celów architektury informacji jest kształtowanie informacji w środowisku, które pozwala użytkownikom tworzyć, zarządzać i udostępniać samą treść w ramach zapewniających relewancję semantyczną; (3) Osobnym celem architektury informacji jest kształtowanie środowiska, aby umożliwić użytkownikom lepszą komunikację, współpracę i wzajemne doświadczenie; (4) Ostatni z celów jest bardziej fundamentalny niż pierwszy: informacja istnieje tylko we wspólnotach znaczeń. Bez innych ludzi informacja nie ma już kontekstu i nie dostarcza informacji; (5) Architektura informacji to przede wszystkim ludzie, a dopiero na drugim miejscu technologia. (Przetłumaczono na podstawie (Hinton, 2002)). Pełny tekst 25 IA Theses znajduje się na stronie archiwalnej Instytutu Architektury Informacji [19.10.2020], http://archive. iainstitute.org/en/learn/research/25_theses.php

${ }^{4}$ Autor szczegółowo omówił zasady D. Browna w: Skórka, 2019.

${ }^{5} \mathrm{~W}$ myśl definicji komunikowania - to celowe przekazywanie informacji od nadawcy do odbiorcy (materialnymi) kanałami (McQuail, 2012, 346). 
211). Innymi słowy, kształt informacji denotuje w sposób jasny jej przeznaczenie. Np. wyraz lub wyrażenie w kolorze niebieskim (niekiedy z podkreśleniem) na ekranie komputera denotuje to, iż jest to link, czyli mechanizm przenoszący do innego miejsca lub treści w środowisku cyfrowym (Rys. 2).

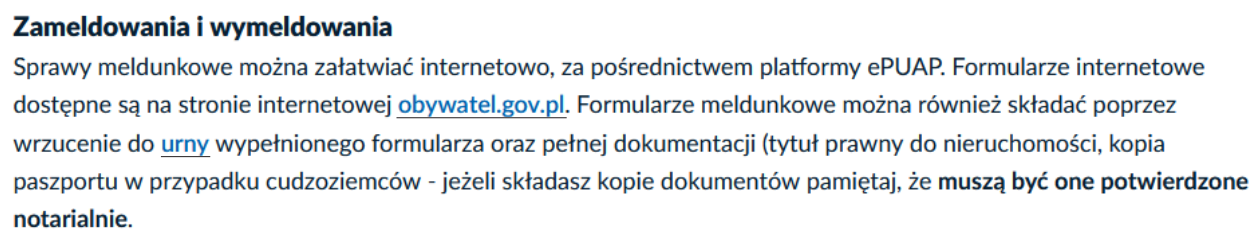

Rys. 2. Fragment treści ze strony Krakow.pl. Widoczne są linki na tle tekstu

Obszerna grupa modeli i teorii dotyczących zachowania ludzi związanego z wyszukiwaniem informacji, opracowanych w nauce o informacji (zob. np. Case \& Given, 2016, 144-175, 187-190; Pulikowski, 2018) również wydaje się dobrym źródłem teoretycznych koncepcji dla badacza architektury informacji, w szczególności systemów organizacji informacji, mechanizmów wyszukiwania i nawigacji. Z powyższych rozważań wynika, iż istnieje pewna grupa teorii, które mogą tworzyć użyteczny fundament dla rozwoju teorii szczegółowych NAI. Rozległy jest również zakres dyscyplin, z których NAI może czerpać inspiracje w przyszłości, rzecz jasna przytoczone wcześniej przykłady nie wyczerpują wszystkich możliwości.

\section{Metodologia NAI}

Interdyscyplinarny charakter badań w architekturze informacji podobnie jak w przypadku wielu innych dyscyplin, m.in. w nauce o informacji (NI) ${ }^{6}$ czy naukach o komunikacji społecznej i mediach (Michalczyk, 2019,17), wyraża się również w różnorodności stosowanych metod badawczych. Metoda badań to ustalony zbiór procedur i zasad wymaganych do uzyskania odpowiedzi na problem postawiony w pytaniu lub hipotezie. Dzięki zastosowaniu właściwej metody badań uzyskane wyniki powinny być rzetelne, pełne, ścisłe oraz adekwatne do odkrywanej rzeczywistości (Apanowicz, 2003, 19).

Wobec dużej liczby metod i technik badawczych zasadne wydaje się pytanie, czy NAI posiada własną metodologię szczegółową, a zatem, czy można wskazać oryginalne metody, typowe dla tej dyscypliny (Hajduk, 2012, 74). W badaniach nad architekturą informacji zastosowanie znajdują narzędzia badawcze opisane w publikacjach omawiających ogólną metodologię badań (Apanowicz, 2003; Hajduk, 2012), jak również w tekstach należących do konkretnych obszarów i dyscyplin, m.in. nauki o informacji (Bawden \& Robinson 2012, 303-324, Cisek, 2013; Pindlowa \& Sosińska-Kalata, 2017; Stefaniak et al., 2016), badań dotyczących zachowań informacyjnych związanych z wyszukiwaniem informacji (Case \& Given, 2016), bibliotekoznawstwa (Ratajewski, 2002), nauki o komunikacji (Michalczyk, 2019), nauk społecznych (Frankfort-Nachmias \& Nachmias, 2001), projektowania

\footnotetext{
${ }^{6}$ Por. Pindlowa \& Sosińska-Kalata, 2017, 727, 729.
} 
graficznego, ekonomii (Stachak, 2013), architektury (Niezabitowska, 2014), informatyki (Sacha, 2010) itd. Ze względu na bogatą literaturę przedmiotu zaakcentowane zostaną tylko wątki związane z głównym tematem niniejszego artykułu.

Architektura informacji posługuje się metodami badawczymi przede wszystkim w praktyce projektowania środowisk informacyjnych, dlatego zdecydowana większość publikacji, które zacytowane zostały poniżej, opisując metodologię w AI, odnosi się do ich zastosowania w działalności projektowej. Dla klarowności dalszych wywodów starano się rozdzielić metody stosowane w architekturze informacji według celu i charakteru badań, w których mogą być zastosowane. Wyodrębniono zatem metody stosowane w działalności:

(1) praktycznej (projektowej) - czyli metody wykorzystywane podczas procesu projektowania, testowania funkcjonalności produktów informacyjnych, projektowania oraz badania elementów architektury informacji (np. systemów nawigacji, systemów wyszukiwania), rozwijające teorie projektowe;

(2) naukowej - czyli metody wykorzystywane w pracy badawczej, kształtującej teorie naukowe, gromadzącej wiedzę, tworzącej paradygmaty itp.?.

Wiele publikacji przybliżających metody i ich zastosowanie jest adresowane do praktyków AI, wprowadzając m.in. w tematykę projektowania i testowania użyteczności stron WWW, interakcji człowieka z komputerem (ang. Human-Computer Interaction), prowadzenia procesu badawczego w ramach ich zadań. Publikacje te wydawane są w postaci przewodników lub podręczników opisujących właściwości metod lub technik oraz instrukcji ich zastosowania (Nunnaly \& Farkas, 2018, 47-75; Hall, 2013). Przykładem takiego przewodnika po metodach jest m.in. obszerne kompendium wiedzy Igi Mościchowskiej i Barbary Rogoś-Turek (2015), skierowane do rodzimych praktyków zatrudnionych w branżach UX/AI. Na rynku wydawniczym ukazały się także tłumaczenia na język polski poradników dotyczących praktycznych technik projektowania wrażeń użytkownika (Nunnally \& Farkas, 2018) oraz projektowania aplikacji mobilnych (Perea \& Giner, 2019). W przytoczonych publikacjach nie pojawia się termin ,architektura informacji”, jednak wykorzystuje ona te same metody i techniki co inne dyscypliny o charakterze praktycznym związane z projektowaniem, jak: inżynieria użyteczności czy interakcja człowiek-komputer. Do tych metod i technik należą: wywiady fokusowe, sortowanie kart, testy użyteczności, testy A/B, metody etnograficzne i obserwacja, eyetracking itp.

Koncepcja metodologii NAI opierać się może na trzech podstawowych funkcjach badań służących rozwiązywaniu problemów w nauce, tj. teoretycznej, metodologicznej i praktycznej (Apanowicz, 2003, 20-21), odpowiadających badaniom podstawowym, diagnostycznym oraz stosownym (Cisek \& Sapa, 2017). Najsłabiej reprezentowaną w publikacjach nt. AI wydaje się być ta pierwsza, co nie zaskakuje w świetle dotychczasowych rozważań. Funkcja teoretyczna polega bowiem m.in. na porównywaniu aktualnych teorii w nauce i wysuwaniu nowych teorii i koncepcji (Apanowicz, 2003, 20). W piśmiennictwie badawczym architektury informacji do nielicznych przykładów prezentacji takich badań należą: monografia Andrei Resminiego i Luki Rosatiego pt. Pervasive Information Architecture (2013), artykuły Flávii Lacerda i Mamede Lima-Marques (2014), A. Resminiego i Sally Buford (2017), M. Roszkowskiego (2019), artykuły zamieszczane cyklicznie w dziale IA Column czasopisma Bulletin

7 Podobnej klasyfikacji dokonała D. Niezabitowska $(2014,41)$ w odniesieniu do metod stosowanych $\mathrm{w}$ architekturze. Autorka ta podzieliła prace badawcze w architekturze na związane z budowaniem teorii projektowania i związane $\mathrm{z}$ budowaniem teorii naukowej. 
of the Association for Information Science and Technology ${ }^{8}$. Funkcja metodologiczna badań pozwala rozwinąć repertuar narzędzi badawczych za sprawą wysuwania hipotez i empirycznej ich weryfikacji, poszukiwania zmiennych i zależności pomiędzy nimi w rozpatrywanych zjawiskach i procesach (Apanowicz, 2003, 20-21). Przykładem z zakresu AI mogą być badania porównawcze architektury informacji w serwisach bibliotek akademickich (Silvis et al., 2019).

Praktyczna funkcja badań polega na stawianiu problemu wynikającego z doświadczenia i świadomej działalności, zastosowaniu określonych metod i technik badawczych (np. eksperymentu, obserwacji, studium przypadku) w celu zbadania struktury i mechanizmów funkcjonowania danego środowiska, a następnie wdrożeniu ich i na tej podstawie opracowaniu wytycznych, np. badania nad interfejsem automatu do kawy (Schneidermeier et al., 2013), zastosowanie metody heurystycznej do ewaluacji interfejsów mobilnych (Gomez et al., 2014), budowanie modeli testowanych empirycznie, a następnie ich wdrażanie, np. koncepcja architektury informacji w modelu zarządzania danymi DIAMANT (Blask \& Förster, 2020). Przykładem metody realizującej stosowaną funkcję badań jest tzw. navigation stress test (test skrajnych warunków nawigacji) Keitha Instone’a (2005), polegający na analizie systemów nawigacji w zakresie realizacji podstawowych ich funkcji, tj. dostarczenia wskazówek na temat lokalizacji użytkownika w serwisie internetowym oraz możliwości wyboru kierunków poruszania.

Posługując się typologią badań marketingowych (Michalski, 2017, 130), prace z zakresu nauki o AI podzielić można według realizowanych funkcji na trzy kategorie badań:

(1) odkrywcze (ang. explorative) - służące poznawaniu i wyjaśnianiu natury zjawisk oraz zagadnień związanych z AI, np. poznawaniu strategii poszukiwania informacji, trendów w projektowaniu interfejsów, zastosowania metod projektowania i ewaluacji itp. Do tego typu badań należą badania porównawcze nad systemami organizacji treści w serwisach internetowych i sklepach stacjonarnych firmy Apple oraz IKEA (np. Potente \& Salvini 2009), zastosowanie klasyfikacji fasetowej w organizacji informacji (Uddin \& Janecek, 2007), badanie dostępności stron bibliotek (Yoon et al., 2016);

(2) rozstrzygające (ang. conclusive) - ich celem jest ustalenie i ocena najlepszego podejścia do danego problemu; szczególnym rodzajem są badania opisowe, które umożliwiają przeprowadzenie charakterystyki cech i objawów zjawisk i procesów, np. omówienie zastosowania metod sortowania kart i testu drzewa (ang. tree test) w badaniach AI (Kaluba, 2020);

(3) przyczynowe (ang. causal) - dochodzące przyczyn i skutków zdarzeń, związków oraz zależności między czynnikami determinującymi określoną aktywność; tego typu badania wyjaśniają również postawy i zachowania użytkowników, np. studium przypadku Rika Peetersa i Arjana Widlaka (2018) na temat zastosowania AI w systemie informacyjnym holenderskiego rejestru stanu cywilnego.

Typologia badań w architekturze informacji może być również analogiczna do podziału badań stosowanych w architekturze ${ }^{9}$. Jeden z podziałów metod badawczych w praktyce projektowej architektury zawiera następujące rodzaje (Niezabitowska, 2014, 42-43):

\footnotetext{
${ }^{8}$ Strona czasopisma Bulletin of the Association for Information Science and Technology oraz link do IA Column: https://asistdl.onlinelibrary.wiley.com/action/doSearch?AllField=iA+column\&startPage$=2$ \&pageSize $=20$

${ }^{9}$ Rodzaje metod omówiono na podstawie T.M de Yong, D. J. M. van der Voordt (ed.) (2002). Ways to Study and Research. Urban, Architectural and Technical Design. Delft: DUP Science (cyt. za Niezabitowska, 2014, 42-43).
} 
(1) badania empiryczne (ang. empirical research), oparte na doświadczeniu, silnie skoncentrowane na opisie rzeczywistości, badaniu teorii i testowaniu hipotez. Ich celem jest również rozwój praktycznych rekomendacji, zaleceń dla projektantów, planistów i ludzi podejmujących decyzje dotyczące polityki firm. Badania te koncentrują się na wiedzy ogólnej i dalszym rozwoju wiedzy ściśle naukowej opartej na doświadczeniu;

(2) badania projektowe (ang. design research) - mają charakter mocno opisowy, poszukiwawczy, odkrywczy, badawczy, a mniej preskryptywny, czyli nakazowy (np. przepis). Zmierzają w kierunku interpretowania, zrozumienia oraz wyjaśnienia projektu i użycia narzędzi projektowych zarówno wewnątrz procesu tworzenia, jak i z odniesieniem do cech miejsca oraz kontekstu społecznego, kulturowego, historycznego, ekologicznego i ekonomicznego. Mogą być pomocne w wywołaniu inspiracji i idei dla danego projektu;

(3) badanie typologiczne (ang. typological research) - szczególna forma badania, charakteryzuje się spojrzeniem wstecz, pozwala odkryć typologię rozwiązań projektowych, nakreślonych przez precedensy. Może być również szczególną formą studiów projektowych (ang. design study) lub studiów w trakcie projektowania (ang. study by design), które skupione są na nowym projekcie. Zogniskowanie zainteresowania może się zmieniać, przechodząc od opisu do odkrywania i testowania, od podejścia empirycznego i opisowego do normatywnego i preskryptywnego (nakazowego);

(4) studia projektowe (ang. design study) są integralną częścią samego procesu projektowego, podczas jego realizacji. Stosuje się w nich analizę, syntezę i ewaluację. Skupione są na szczegółach dotyczących projektu. Pozwalają odkrywać nowe możliwości rozwiązań, wiedzę na dany temat, prowadzą do lepszego zrozumienia celu, pozwalając na podjęcie właściwych decyzji w procesie projektowania;

(5) studia w trakcie projektowania (ang. study by design), studia w projektowaniu, ich celem jest wygenerowanie, tworzenie wiedzy i nowego wglądu poprzez studiowanie przekształceń, przeobrażeń, transformacji projektowych albo projektowych interwencji w określonej sytuacji. Cechują się eksploracyjnym charakterem. Istotnym etapem jest wytwarzanie nowych wariantów projektu, czyli tzw. zorientowanie na zasoby, dzięki czemu studia te mogą prowadzić do adaptacji istniejących lub odmiennych rozwiązań.

Jak wynika z dotychczasowych rozważań, trudno jest jednoznacznie wskazać metodę badawczą ściśle związaną z NAI. Wyjątkiem może być navigation stress test oraz metoda sortowania kart używana m.in. podczas opracowywania systemów organizacji informacji (Spencer, 2009), przez co stosowana jest często w praktyce projektowej. NAI, podobnie jak wiele dyscyplin, korzysta $\mathrm{z}$ bogatego zasobu metod wymienionych w niniejszym rozdziale, dobieranych w zależności od problemu badawczego, kontekstu i określonego podejścia projektowego lub badawczego.

\section{Kształcenie akademickie w zakresie AI}

Odwołując się do definicji dyscypliny naukowej opartej na kryteriach instytucjonalnych, zgodnie z którą jest to „dziedzina wiedzy wykładana na wyższej uczelni i uprawiana w ramach wydziału lub instytutu" (Kozłowski, 1996, 4), autor dokonał przeglądu kierunków 
studiów z zakresu AI. Od kilkunastu lat istnieją na świecie ośrodki kształcące specjalistów $\mathrm{z}$ architektury informacji. W $2014 \mathrm{r}$. zajęcia na poziomie akademickim prowadzone były w 13 krajach, m.in. w: Australii, Kanadzie, Chile, Danii, Francji, we Włoszech, Szwecji, Wielkiej Brytanii i oczywiście w Stanach Zjednoczonych ${ }^{10}$.

Jedną z pierwszych uczelni, która uruchomiła kierunek studiów o tej nazwie był Kent State University (Stany Zjednoczone). Były to studia Information Architecture and Knowledge Management (IAKM), prowadzone na poziomie magisterskim ${ }^{11}$, a za ich program odpowiadał prof. Thomas Froehlich. Program IAKM zapewniał kształcenie w trzech obszarach: architektura informacji, w ramach której uczono projektowania systemów danych i interfejsów używanych przez firmy; zarządzanie wiedzą, którego celem jest udostępnienie zbiorowego know-how i doświadczeń organizacji; oraz wykorzystanie informacji (ang. information use), które koncentruje się na tym, w jakim stopniu osiągane są cele w zakresie dostępu, użyteczności i wydajności ${ }^{12}$.

Na Aalborg University (Dania) prowadzony jest kierunek magisterski The Master's Programme in Information Architecture ${ }^{13}$. Przy Uniwersidade de Brasilia (Brazylia) działa specjalny instytut zajmujący się badaniami z zakresu AI o nazwie CPAI - Centro de Pesquisa em Arquitetura da Informação ${ }^{14}$ (Centrum Badawcze Architektury Informacji). Oprócz tego, przedmiot o tej nazwie można studiować, m.in. na kierunku licencjackim New Media Design w Jönköping University (Szwecja) ${ }^{15}$ oraz Interaction Design: Graphical User Interfaces w Malmö University (Szwecja) ${ }^{16}$.

W Polsce kierunek studiów o nazwie architektura informacji lub architektura przestrzeni informacyjnych prowadzą uczelnie, które wcześniej kształciły studentów z zakresu informacji naukowej i bibliotekoznawstwa, jest to trend zauważalny także na świecie. Architekturę informacji na poziomie licencjackim można studiować na: Uniwersytecie Pedagogicznym w Krakowie (jako pierwszy w kraju otworzył kierunek studiów licencjackich w 2013 r.), Uniwersytecie Marii Curie-Skłodowskiej w Lublinie, Uniwersytecie Mikołaja Kopernika w Toruniu, Uniwersytecie Śląskim w Katowicach oraz Uniwersytecie Warszawskim, który prowadzi kierunek Architektura Przestrzeni Informacyjnych. Studia w zakresie AI na poziomie magisterskim oferują Uniwersytet Marii Curie-Skłodowskiej i Uniwersytet Mikołaja Kopernika w Toruniu oraz od roku 2021/22 - Uniwersytet Warszawski (RADON, 2021). Temat kształcenia z zakresu AI wymaga głębszych analiz zarówno od strony merytorycznej jak i organizacyjnej.

${ }^{10}$ Na podstawie danych ze strony IA Institute: Schools Teaching IA: http://archive.iainstitute.org/en/ learn/education/schools_teaching_ia.php

11 Kierunek został utworzony w 2001 r. zob. https://www.kent.edu/iSchool/news/information-architecture-and-knowledge-management-celebrate-10th-anniversary [dostęp 24. 08.2020].

${ }_{12}$ Na podst. ulotki reklamowej Kent State University z 2008 r.: https://www.iainstitute.org/sites/default/ files/ia_insert_fortune_2008jan21.pdf [dostęp 24.08.2020].

13 Information Architecture, Master. W: Aalborg University: https://www.students.aau.dk/educations-without-admission/information-architecture

14 Strona CPAI - Centro de Pesquisa em Arquitetura da Informação: https://unb.academia.edu/Departments/CPAI_Centro_de_Pesquisa_em_Arquitetura_da_Informa\%C3\%A7\%C3\%A3o

15 Na podstawie witryny Jönköping University: https://ju.se/en/study-at-ju/our-programmes/bachelor-programmes/new-media-design.html

${ }^{16}$ Na podstawie witryny: https://edu.mau.se/en/course/kd401b 


\section{Przyszłość NAI oraz wnioski}

Prognozowanie czy rozwój badań dotyczących problematyki AI doprowadzi do wyodrębnienia się samodzielnej dyscypliny, czy też pozostaną one obszarem badawczym informatologii lub dyscypliny user experience, a AI traktowana będzie jako tylko działalność praktyczna jest trudnym zadaniem. Bez wątpienia NAI, której koncepcja nakreślona została w artykule, wiążą silne relacje z nauką o informacji (Tafiłowski, 2016), a tym samym z nauką o komunikacji społecznej i mediach, w skład której od 2018 r. formalnie wchodzi nauka o informacji. Bliskość tych relacji oraz różnorodność koncepcji nauki o informacji sprawiają, iż ustalenie wyraźnych granic między NI a NAI jest skomplikowane. Poszukiwania cech odróżniających obie dyscypliny w literaturze przedmiotu z informatologii (Bawden \& Robinson, 2012, 2; Cisek, 2007; Górny, 2016, 33-35; Pindlowa \& Sosińska-Kalata, 2017, 725-726) pozwoliły zidentyfikować oryginalne cechy, dzięki którym możliwe jest zarysowanie obszarów badawczych właściwych dla każdej z wymienionych dyscyplin pod warunkiem przyjęcia określonej koncepcji rozumienia nauki o informacji. Do szczególnie często wymienianych pól zainteresowań NI należą: praktyczne i teoretyczne aspekty działalności informacyjnej, wykorzystywane w niej metody i narzędzia, tj. systemy i źródła informacji, procesy informacyjne (gromadzenie, przechowywanie i wykorzystanie informacji) oraz zachowania użytkowników informacji i usług informacyjnych (Sosińska-Kalata, 2017, 725). Dodatkowo uznaje się, że badanie obiektów i procesów związanych z informacją dotyczy zarówno działalności naukowej, gospodarczej i publicznej (Górny, 2016, 33, 35), jak i aktywności człowieka w jego codziennym życiu (Kamińska-Czubała, 2013; Savolainen, 1995). Z kolei zakres badań nauki o architekturze informacji obejmuje teorię i praktykę procesu projektowania i ewaluacji funkcjonalności oraz użyteczności produktów informacyjnych, badanie właściwości interakcji z nimi w środowiskach i ekosystemach informacyjnych wykorzystywanych w różnych obszarach działalności człowieka - zarówno w nauce, jak i w edukacji, rozrywce czy biznesie (Tab. 1). Do przedmiotów jej badań należą elementy AI, m.in.: schematy i systemy organizowania informacji, nawigacji, wyszukiwania, interfejsy, kod, kształt komunikatu. Celem badań NAI jest natomiast przede wszystkim analiza czynników wpływających na ułatwianie użytkownikowi zrozumienia i wykorzystania przekazywanych treści poprzez dostosowanie elementów architektury informacji (np. nawigacji, kodu, kształtu) do potrzeb użytkowników. Obszar badań NI jest znacznie szerszy niż obszar badań NAI, ponieważ obejmuje wieloaspektową problematykę funkcjonowania człowieka w świecie utrwalonej informacji i zapewnienia sprawnego dostępu do informacji jednostkom i społeczeństwom w każdej sferze życia i w każdym środowisku informacyjnym. Nauka o architekturze informacji natomiast skupia się na węższym obszarze problemowym, związanym z procesem projektowania pewnego środowiska informacyjnego. Pole badawcze NI obejmuje również ten proces i jego uwarunkowania, jednak zagadnienia związane z projektowaniem środowiska informacyjnego, które ma spełniać określone oczekiwania są rozporoszone wśród wielu kierunków badań tej dyscypliny. 
Tab. 1. Zestawienie cech charakterystycznych nauki o architekturze informacji według kryteriów oceny odrębności dyscyplin naukowych

\begin{tabular}{|c|c|}
\hline $\begin{array}{c}\text { Kryteria } \\
\text { odrębności } \\
\text { dyscypliny } \\
\text { naukowej }\end{array}$ & $\begin{array}{c}\text { Cechy charakterystyczne } \\
\text { nauki o architekturze informacji }\end{array}$ \\
\hline $\begin{array}{l}\text { Przedmiot } \\
\text { zainteresowań }\end{array}$ & $\begin{array}{ll}\text { - } & \text { środowisko informacji i jego architektura: systemy organizacji informacji, } \\
& \text { nawigacji, wyszukiwania, etykietowania } \\
\text { - } & \text { teoretyczne i praktyczne aspekty projektowania funkcjonalnych produk- } \\
& \text { tów informacyjnych } \\
\text { - } & \text { metody i narzędzia stosowane w procesie projektowania i ewaluacji eko- } \\
& \text { systemów informacyjnych } \\
- & \text { formy (kształty) informacji: interfejsy, mapy, instrukcje itp. } \\
- & \text { strategie i sposoby wyszukiwania informacji } \\
- & \text { rodzaje interakcji użytkownika z informacją } \\
- & \text { kształcenie w zakresie AI }\end{array}$ \\
\hline Teorie & $\begin{array}{ll}\text { - } & \text { koncepcja powszechnej architektury informacji (ang. pervasive informa- } \\
& \text { tion architecture) A. Resminiego i Luci Rosatiego (2011) } \\
- & \text { koncepcja międzykanałowej AI (cross-channel IA) (Resmini, Rosati, 2011, 10) } \\
- & \text { perspektywa hermeneutyczna AI (Roszkowski, 2019) } \\
- & 25 \text { tez architektury informacji } \\
- & \text { osiem zasad AI Dana Browna (2010) } \\
- & \text { teoria zdobywania informacji (information foraging theory) oraz tropu } \\
& \text { informacji (information scent) P. Pirollego (2007) } \\
- & \text { teoria komunikacji „forma idzie za funkcją” (Eco, 2003, 211) - kształt } \\
& \text { informacji denotuje jej przeznaczenie } \\
- & \text { teoria budowy przestrzeni architektonicznej Kevina Lyncha (2011) } \\
- & \text { wayfinding (odkrywania drogi) Romedi Passiniego (1992) } \\
- & \text { teorie związane z wyszukiwaniem informacji } \\
- & \text { teorie związane z organizacja informacji }\end{array}$ \\
\hline $\begin{array}{l}\text { Metody } \\
\text { i techniki } \\
\text { badawcze }\end{array}$ & $\begin{array}{l}\text { - Navigation stress test } \\
\text { - } \text { metoda porównawcza } \\
\text { - } \text { metoda analizy dokumentów (krytyki piśmiennictwa) } \\
\text { - } \text { metoda sondażowa } \\
\text { - } \text { metoda dialogowa } \\
\text { - } \text { metoda heurystyczna } \\
\text { - obserwacja } \\
\text { - } \text { studium przypadku }\end{array}$ \\
\hline Zakres & - ekosystemy informacyjne (fizyczne i cyfrowe) \\
\hline Cele badawcze & $\begin{array}{ll}\text { - } & \text { odpowiedź na pytanie: dlaczego informacja informuje? } \\
\text { - } & \text { funkcje elementów AI ułatwiające wyszukiwanie i zrozumienie informacji } \\
\text { - } & \text { usprawnienie procesu przekazywania informacji oraz interakcji człowieka } \\
& \text { z informacją } \\
\text { - } & \text { rozwój metodologii badawczej i projektowej } \\
\text { - } & \text { ocena użyteczności środowisk i produktów informacyjnych } \\
\text { - } & \text { badanie ewolucji architektury informacji }\end{array}$ \\
\hline
\end{tabular}


Podsumowując tę część rozważań, można stwierdzić, że NAI skupia się na projektowaniu optymalnych rozwiązań organizacyjnych i technicznych dla realizacji procesu informacyjnego w określonym środowisku, łącząc czynnik architektury, tj. projektowania środowiska informacyjnego jako syntezy wielu części tworzących pewną funkcjonalną całość, oraz czynnik informatologii, tj. badania uwarunkowań procesów informacyjnych zachodzących w tym środowisku, które ma zapewnić lepsze poznanie uwarunkowań i usprawnienie interakcji człowieka z produktem informacyjnym poprzez odpowiednie wykonanie elementów ułatwiających zrozumienie i wyszukanie informacji.

Nawiązując do postawionego na wstępie pytania o to, czy AI może być samodzielną dyscypliną naukową, autor, na podstawie przeprowadzonej analizy, odpowiada twierdząco. Zadaniem nauki o AI może być badanie zjawisk wpływających na odnajdywanie informacji przez człowieka, ale także na efektywność w zarządzaniu informacją, w tym również poszukiwanie nowych narzędzi, metod, inspiracji do wspierania tych działań. Jednym z celów badaczy architektury informacji może być poszukiwanie odpowiedzi na pytanie, czy forma informacji wyraża jej przeznaczenie i co o tym decyduje.

Elżbieta D. Niezabitowska $(2014,98)$ na przykładzie rozwoju architektury od działalności praktycznej do naukowej opisała czteropoziomowy rozwój dyscypliny naukowej, który można też zastosować w odniesieniu do nauki o architekturze informacji:

Poziom 1: faza przednaukowa: wdrażanie gotowych rozwiązań praktycznych i osiągnięć naukowych, gromadzenie w codziennej działalności faktów, np. analiza skuteczności elementów architektury informacji w określonych rodzajach serwisów internetowych.

Poziom 2: praktyczno-wdrożeniowy, podejmowanie działań badawczych w praktyce (ekspertyzy, obserwacje), wykorzystywanie zebranych danych i wyników badań w celu poprawy istniejącej rzeczywistości, np. wprowadzenie ikonograficznego elementu „hamburger menu" w pasku nawigacyjnym aplikacji mobilnej.

Poziom 3: naukowy, charakteryzuje się prowadzeniem badań podstawowych, obserwowaniem wybranych zjawisk w celu poznania ich mechanizmów, formułowaniem pytań badawczych i poszukiwaniem na nie odpowiedzi, budowaniem nowych hipotez i teorii na podstawie badań interdyscyplinarnych i transdyscyplinarnych, pojawia się zaawansowana refleksja filozoficzna na poziomie etycznym i poznawczym, np. szukanie odpowiedzi na pytanie: na ile forma informacji implikuje jej funkcję i ułatwia jej wykorzystanie.

Poziom 4: rozwojowo-wdrożeniowy, cechuje go upowszechnianie osiągnięć naukowych, prowadzenie badań wdrożeniowych, opracowanie zasad, wytycznych, standardów w oparciu o osiągnięcia nauki.

Na podstawie przytoczonych wytycznych można postawić tezę, iż NAI znajduje się w fazie przejściowej między poziomem 2 a 3. Wydaje się, że osiągnięty już został poziom praktyczno-wdrożeniowy, widoczny jest jednak niedosyt refleksji o charakterze filozoficznym, która dopiero zaczyna pojawiać się w dyskursie akademickim $\mathrm{AI}^{17}$. Nauka o architekturze informacji ukształtowana została w wyniku niespotykanego wcześniej zalewu informacją i jej formami, postępującą cyfryzacją treści i jej łączeniem w sieć relacji. Za sprzyjający jej rozwojowi można uznać także rozwój e-handlu, który dotychczas jest największym

17 M.in. podczas konferencji „Architektura informacji jako dyscyplina akademicka (AIDA)” organizowanych przez Instytut Nauk o Informacji Uniwersytetu Pedagogicznego w Krakowie oraz World Information Architecture Day organizowanych na Uniwersytecie Mikołaja Kopernika w Toruniu. 
beneficjentem rezultatów pracy architektów informacji. NAI przeżywa obecnie etap ewolucji od interdyscyplinarnego obszaru badawczego do samodzielnej dyscypliny, zajmującej się teoretycznymi i praktycznymi kontekstami projektowania i kształtowania środowisk informacyjnych w formach zapewniających skuteczność wyszukiwania i zarządzania informacją oraz ułatwiających jej zrozumienie. Kończąc niniejsze rozważania, autor raz jeszcze odwoła się do wspomnianych już 25 tez architektury informacji, by zacytować jako prognozę dwie ostatnie mówiące, iż:

- Architektura informacji to najpierw czynność, potem praktyka, i wreszcie dyscyplina.

- Dzielenie się praktyką rozwija dyscyplinę i wzmacnia ją ${ }^{18}$.

\section{Bibliografia}

Apanowicz, J. (2003). Metodologia nauk. Toruń: Dom Organizatora TNOiK.

Babik, W. (2019). Zarządzanie informacją - ważne wyzwanie współczesności. W: W. Babik (red.), Zarzadzanie informacja (15-32). Warszawa: Wydaw. Naukowe i Edukacyjne SBP.

Bates, M. J. (2007). Defining the Information Disciplines in Encyclopedia Development. Information Research, 12(4) Paper COLIS29 [7.11.2020], http://InformationR.net/ir/12-4/colis/colis29.html

Bawden, D., Robinson, L. (2012). Introduction to Information Science. London: Facet Publishing.

Blask, K., Förster, A. (2020). Designing an Information Architecture for Data Management Technologies: Introducing the DIAMANT Model. Journal of Librarianship and Information Science, 52 (2), 592-600, https://doi.org/10.1177/0961000619841419

Brown, D. (2010). Eight Principles of Information Architecture. Bulletin of the American Society for Information Science and Technology, August/September, 36 (6), 30-34, https://doi.org/10.1002/ bult.2010.1720360609

Case, D.O., Given, L.M. (2016). Looking for Information: A Survey of Research on Information Seeking, Needs, and Behavior. 4th ed. Bingley: Howard House, Emerald Group.

Cisek, S. (2007). Nauka o informacji na świecie w XXI wieku: badania metanaukowe [online]. e-LIS [5.01.2021], http://eprints.rclis.org/11098/1/Cisek_in_na_swiecie_eng.pdf

Cisek, S. (2013). Metodologia jakościowa we współczesnej informatologii. Wybrane aspekty. Przeglad Biblioteczny, 81 (3), 299-310.

Cisek, S., Sapa, R. (2017). Diagnostyczny potencjał informatologii [online]. W: R. Sapa (red.), Diagnostyka w zarzadzaniu informacja: perspektywa informatologiczna (15-33). Kraków: Biblioteka Jagiellońska [5.01.2021], https://ruj.uj.edu.pl/xmlui/handle/item/48809

Dade-Robertson, M. (2011). The Architecture of Information. Architecture, Interaction Design and the Patterning of Digital Information. London: Routledge.

Davis, N. (2010). Information Architecture, Black Holes and Discipline: On Developing a Framework for a Practice of Information Architecture. Bulletin of the American Society for Information Science and Technology, 36 (6), 25-29, https://doi.org/10.1002/bult.2010.1720360608

Davis, N. (2011). The T-Model and Strategies for Hiring IA Practicioners: Part 1 [online]. UXmatters [7.11.2020], https://www.uxmatters.com/mt/archives/2011/10/the-t-model-and-strategies-forhiring-ia-practitioners-part-1.php

Davis, N. (2012). Understanding Information Architecture Differently [online]. UXMatters [7.11.2020], https://www.uxmatters.com/mt/archives/2012/05/understanding-information-architecturedifferently.php

Davis, N. (2018). What is Information Architecture? [online]. Methodbrain [7.11.2020], https://methodbrain.com/2018/10/08/what-is-information-architecture/\#information-architecture-science

\footnotetext{
${ }^{18}$ Por. 25 Theses: http://archive.iainstitute.org/en/learn/research/25_theses.php
} 
Dijck Van, P. (2003). Information Architecture for Designers. Structuring Websites for Business Success. Mies: RotoVision SA.

Dillon, A. (2003). Measuring Progress in a Complicated World. Bulletin of the American Society for Information Science and Technology, February/March, 29 (3), 27, https://doi.org/10.1002/bult.278

Eco, U. (2003). Nieobecna struktura. Warszawa: Wydaw. KR.

Fast, K. (2006). The Confluence of Research and Practice in Information Architecture. Bulletin of the American Society for Information Science and Technology, 32 ( 5), 27, https://doi.org/10.1002/ bult.2006.1720320510

Frankfort-Nachmias, Ch., Nachmias, D. (2001). Metody badawcze w naukach spotecznych. Poznań: Zysk i S-ka.

Garret, J.J. (2002). IA/recon. Part 1 of 6: The Discipline and the Role [online]. jjg.net [7.11.2020], http://www.jjg.net/ia/recon/\#part1

Gomez, R.Y., Cascado-Caballero D., Sevillano, J.L. (2014). Heuristic Evaluation on Mobile Interfaces: A New Checklist. The Scientific World Journal. Article ID 434326, 19 pages, http://dx.doi. org/10.1155/2014/434326

Górny, M. (2016). Nauka o informacji jako dyscyplina naukowa. W: W. Babik (red.), Nauka o informacji (23-40). Warszawa: Wydaw. Naukowe i Edukacyjne SBP.

Hall, E. (2013). Just Enough Research. New York: A Book Apart.

Haverty, M. (2002). Information Architecture Without Internal Theory: An Inductive Design Process. Journal of the American Society for Information Science and Technology, 53(10), 839-845, https:// doi.org/10.1002/asi.10096

Hinton, A. (2002). 25 Theses [online]. The Information Architecture Institute [7.11.2020], http:// archive.iainstitute.org/en/learn/research/25_theses.php

Hjørland, B. (2012). A Fascinating Field and a Pragmatic Enterprise. In: D. Bawden \& L. Robinson (eds), Introduction to Information Science (xxi-xxiii). London: Facet Publishing.

Hubert-Miller de, B.A. (2006). The IA of Potentiality: Toward a Grounded Theory of Information Architecture. Philosophy, Theory and Research. Bulletin of the American Society for Information Science and Technology; August/September, 32 (6), 10-12, https://doi.org/10.1002/bult.2006.1720320605

Ingwersen, P. (1995). Information and Information Science. In: A. Kent (ed.) Encyclopedia of Library and Information Science. Vol. 56, suppl. 19. (137-174). New York: Marcel Dekker.

Instone, K. (2005). About the Navigation Stress Test [online]. Keith Instone [10.01.2021], http:// instone.org/navstress/about

Kalbach, J. (2007). Designing Web Navigation. Beijing: O’Reilly Media.

Kaluba, P. (2020). „Gdzie to znajdę?”, czyli wnioski z badań dotyczących architektury informacji. Online Marketing [10.01.2021], (50) luty-marzec, 22-26, https://o-m.pl/artykul/gdzie-to-znajdeczyli-wnioski-z-badan-dotyczacych-architektury-informacji

Kamiński, S. (1992). Nauka i metoda. Pojęcie nauk i klasyfikacja nauk. Wyd. 4. Lublin: Tow. Nauk. KUL.

Kamińska-Czubała, B. (2013). Zachowania informacyjne w życiu codziennym : informacyjny świat pokolenia Y. Warszawa: Wydaw. SBP.

Kisilowska, M. (2011). Przestrzeń informacyjna jako termin informatologiczny. Zagadnienia Informacji Naukowej, 49(2), 35-52, https://doi.org/10.36702/zin.666

Kozłowski, J. (1996). Narodziny i rozwój dyscyplin naukowych. Sprawy Nauki, (1), 3-8.

Lacerda, F., Lima-Marques, M. (2014). Information Architecture as a Discipline: A Methodological Approach. In: A. Resmini (ed.), Reframing Information Architecture (1-10). Cham: Springer.

Lindsay, P.H., Norman D. A. (1984). Procesy przetwarzania informacji u człowieka: wprowadzenie do psychologii. Warszawa: PWN.

Ludwin, K. (2017). O kolorze w architekturze. Kraków: Politechnika Krakowska.

Lynch, K. (2011). Obraz miasta. Kraków: Wydaw. Archivolta Michał Stępień.

McQuail, D. (2012). Teoria komunikowania masowego. Warszawa: PWN. 
Michalczyk, S. (2019). Teoria komunikowania masowego. Skrypt dla studentów dziennikarstwa $i$ komunikacji społecznej. Katowice: Wydaw. Uniwersytetu Śląskiego.

Michalski, E. (2017). Marketing. Podręcznik akademicki. Wyd. 2. Warszawa: Wydaw. PWN.

Morville, P. (2004). Information Architecture Research [online]. Semanticstios.com [7.11.2020], https://semanticstudios.com/information_architecture_research/.

Morrogh, E. (2002). Information Architecture. An emerging 21st Century Profession. Upper Saddle River: Prentice Hall.

Monestiroli, A. (2004). Osiem definicji architektury. Pretekst. Zeszyty Katedry Architektury Mieszkaniowej, 1, 9-16.

Mościchowska, I., Rogoś-Turek, B. (2015). Badania jako podstawa projektowania user experience. Warszawa: Wydaw. PWN.

Niezabitowska, E. D. (2014). Metody i techniki badawcze w architekturze. Gliwice: Wydaw. Politechniki Śląskiej.

Nunnaly, B., Farkas, D. (2018). Badanie UX. Praktyczne techniki projektowania bezkonkurencyjnych produktów. Gliwice: Helion.

Passini, R. (1992). Wayfinding in Architecture. New York: Van Nostrand Reinhold.

Pawłowski, A. (2009). Nauka o mediach i komunikacji. Próba oceny stanu dyscypliny. W: M. Filiciak i G. Ptaszek (red.), Komunikowanie (się) w mediach elektronicznych. Język, edukacja, semiotyka. Monografia (15-28). Warszawa: Wydaw. Akademickie i Profesjonalne.

Peek, R. (2000). ASIS Summit 2000: Defining Information Architecture. Information Today, June, 17 (6), 14, 16,18, https://doi.org/10.1002/bult.167

Peeters,R., Arjan Widlak, A. (2018). The Digital Cage: Administrative Exclusion Through Information Architecture - The Case of the Dutch Civil Registry's Master Data Management System. Government Information Quarterly 35 (2), 175-183, https://doi.org/10.1016/j.giq.2018.02.003

Perea P., Giner, P. (2019). UX Design. Projektowanie aplikacji dla urzadzeń mobilnych, Gliwice: Helion. Pieter J. (1960). Praca naukowa. Katowice: Wydaw. Śląsk.

Pindlowa, W., Sosińska-Kalata, B. (2017). Informatologia. W: A. Żbikowska-Migoń i M. Skalska-Zlat (red.), Encyklopedia ksiażki. T 1. Eseje. A-J (725-731). Wrocław: Wydaw. Uniwersytetu Wrocławskiego.

Pirolli, P. (2007). Information Foraging Theory. Adaptive Interaction with Information. Oxford: Oxford: Univ. Press.

Potente, D., Salvini, E. (2009). Apple, IKEA and Their Integrated Architecture. Bulletin of the American Society for Information Science and Technology, 35(4), 32-42, https://doi.org/10.1002/ bult.2009.1720350411

Pulikowski, A. (2018). Modelowanie procesu wyszukiwania informacji naukowej. Strategie i interakcje. Katowice: Wydaw. Uniwersytetu Śląskiego.

RADON (2021). Studia prowadzone na określonym kierunku [online]. RADON - raporty, analizy, dane [23.07.2021], https://radon.nauka.gov.pl/dane/studia-prowadzone-na-okreslonym-kierunku

Ratajewski, J. (2002). Wprowadzenie do bibliotekoznawstwa, czyli wiedza o bibliotece w różnych dawkach. Warszawa: Wydaw. SBP.

Resmini, A., Buford, S. (2017). Cross-channel Information Architecture for a World Exposition. International Journal of Information Management, 37(6), 547-552, https://doi.org/10.1016/j. ijinfomgt.2017.05.010

Resmini, A., Rosati, L. (2011). Pervasive Information Architecture. Designing Cross-Channel User Experience. Amsterdam: Morgan Kaufman.

Rosenfeld, L., Morville, P., Arango, J. (2017). Architektura informacji w serwisach internetowych i nie tylko. Wyd. 4. Gliwice: Helion.

Roszkowski, M. (2019). Każda reprezentacja jest interpretacją - w stronę hermeneutycznej koncepcji architektury informacji. Zagadnienia Informacji Naukowej, 57 (2), 61-79, https://doi. org/10.36702/zin.455 
Sacha, K. (2010). Inżynieria oprogramowania. Warszawa: Wydaw. Naukowe PWN.

Saffer, D. (2010). Designing for Interaction: Creating Innovative Applications and Devices. Berkely: New Riders.

Savolainen, R. (1995). Everyday Life Information Seeking: Approaching Information Seeking in the Context of "Way of Life". Library E Information Science Research, 17 (3), 259-294, https://doi. org/10.1016/0740-8188(95)90048-9

Schneidermeier, T., Burgardt, M., Wolff, Ch. (2013). Design Guidelines for Coffee Vending Machines. In: A. Marcus (ed.), Design, User Experience, and Usability. Web, Mobile, and Product Design. Second International Conference, DUXU 2013 Held as Part of HCI International 2013 Las Vegas, NV, USA, July 21-26, 2013. Proceedings, Part IV (432-440). Berkeley: Springer.

Silvis, I. M., Bothma, T. J.D. Beer, K. J.W. de (2019). Evaluating the Usability of the Information Architecture of Academic Library Websites . Library Hi Techi,. 37 (3), 566-590, https://doi.org/10.1108/ LHT-07-2017-0151

Skórka, S. (2016). Architektura informacji. W: W. Babik (red.), Nauka o informacji (555-575). Warszawa: Wydaw. Naukowe i Edukacyjne SBP.

Skórka, S. (2019). Architektura informacji w praktyce zarządzania zasobami informacyjnymi. W: W. Babik (red.), Zarzadzanie informacja (190-209). Warszawa: Wydaw. Naukowe i Edukacyjne SBP.

Sosińska-Kalata, B. (2013). Obszary badań współczesnej informatologii (nauki o informacji). Zagadnienia Informacji Naukowej, 51 (2), 9-41, https://doi.org/10.36702/zin.600

Sosińska-Kalata, B. (2017). Architektura informacji. W: A. Żbikowska-Migoń i M. Skalska-Zlat (red.), Encyklopedia ksiażki T 1. Eseje. A-J (161-162). Wrocław: Wydaw. Uniwersytetu Wrocławskiego.

Spencer, D. (2010). A Practical Guide to Information Architecture. Penarth: Five Simple Steps.

Spencer, D. (2009). Card Sorting. Designing Usable Categories. New York: Rosenfeld Media.

Stachak, S. (2013). Podstawy metodologii nauk ekonomicznych. Warszawa: Diffin.

Stefaniak, B., Skalska-Zlat, M., Cisek, S. (2016). Metody badań w nauce o informacji (informatologii). W: W. Babik (red.), Nauka o informacji (89-122). Warszawa: Wydaw. Naukowe i Edukacyjne SBP.

Teoria naukowa (b.d.). Encyklopedia PWN [online]. [17.10.2020], https://encyklopedia.pwn.pl/ szukaj/teoria\%20naukowa.html

Tafiłowski, P. (2016). Architektura informacji jako problem badawczy informatologii. Zagadnienia Informacji Naukowej, 54 (2), 37-47, https://doi.org/10.36702/zin.302

Uddin, M. N., Janecek, P. (2007). Faceted Classification in Web Information Architecture. The Electronic Library, 25 (2), 219-233, https://doi.org/10.1108/02640470710741340.

Utracka, D. (2017). Humanistyczne aspekty architektury informacji. Rekonesans. Zagadnienia Rodzajów Literackich, (3), 173-189.

Wurman, R. S., Katz J. (1975). Beyond Graphics: The Architecture of Information [online]. AIA Journal, 63(4), 40, 56 [7.11.2020], https://www.usmodernist.org/AJ/AJ-1975-10.pdf

Wurman, R.S. (1997). Information Architects. New York: Graphis Inc.

Yoon, K., Hulscher, L., Dols, R. (2016). Accessibility and Diversity in Library and Information Science: Inclusive Information Architecture for Library Websites. The Library Quarterly, 86(2), 213-229, https://doi.org/10.1086/685399 


\title{
Information Architecture as a Science: The Concept of a Scientific Discipline
}

\begin{abstract}
Purpose/Thesis: The aim of this paper is to determine whether information architecture (IA) is a scientific discipline and what distinguishes IA from information science.

Approach/Methods: The study employed a literature review and the comparative method. IA's status as a scientific discipline was examined with reference to three criterions: field of research, theory, and methodology.

Results and conclusions: IA science (IAS) applies paradigms and theories from other disciplines, i.e.: architecture, information science, media, and communication studies. The goals of IAS are: studying the phenomena affecting the information search process and the efficiency of information management, examining the new tools, methods, and inspirations. Researchers investigate whether the form of information expresses its function. It is difficult find an original IA research method.

Originality/Value: IAS differs from IS in that IS focuses on the nature of information, analysing its features and attributes, considering the entire information process, whereas IAS is more concerned with information seeking, efficiency of information management, and identifying the factors that affect the understanding of information.
\end{abstract}

\section{Keywords}

Information architecture. Information science. Interdisciplinarity. Methodology. Scientific discipline. Research field. Theory.

STANISŁAW SKÓRKA jest doktorem nauk humanistycznych, adiunktem w Instytucie Nauk o Informacji Uniwersytetu Pedagogicznego w Krakowie oraz dyrektorem Biblioteki Głównej tej uczelni. Zainteresowania badawcze: architektura informacji, projektowanie i ocena użyteczności systemów informacji, systemy nawigacji, web design, Internet Reczy. Najważniejsze publikacje: Architektura informacji. Historia idei (Czasopismo Zakładu Narodowego im. Ossolińskich 2020), Internet Rzeczy jako pole zainteresowań architektury informacji (Annales Universitatis Paedagogicae Cracoviensis. Studia ad Bibliothecarum Scientiam Pertinentia, 2019), Architektura informacji (W. Babik, red., Nauka o informacji, 2016).

\author{
Kontakt $z$ autorem: \\ stanislaw.skorka@up.krakow.pl \\ Instytut Nauk o Informacji \\ Uniwersytet Pedagogiczny w Krakowie \\ ul. Podchorażych 2 \\ 30-084 Kraków
}

